\title{
Paranoia og paranoid
}

\author{
I norsk psykiatri blander man ofte sammen begrepene «paranoia» \\ og «paranoid». Jeg vil foreslå å sløyfe begrepet «paranoide psykoser» \\ og bruke betegnelsen «vrangforestillingslidelser», slik man gjør \\ i ICD-10 og i den engelske og svenske utgaven.
}

«Paranoia» er et mer enn to tusen år gammelt begrep. Direkte oversatt betyr det «på siden av fornuften», og omfattet den gang galskap eller sinnssykdom i sin alminnelighet. Enkelte brukte synonymparet «insania» og «vesania» i samme betydning (1). Paranoia rommet altså svært mange av dagens mer enn 300 spesifiserte psykiatriske diagnoser. Emil Kraepelin (1856-1926), som regnes som grunnleggeren av systematisk deskriptiv psykiatrisk klassifikasjon, brukte begrepet paranoia om systematiserte vrangforestillinger (1).

Ordet «paranoid» betyr direkte oversatt paranoialiknende, idet tilstanden likner på hovedlidelsen paranoia (gresk: eidos $=$ likne på). I en norsk lærebok i psykiatri står det: «Paranoide lidelser eller «delusional disorders» er i dag en gyldig nosologisk gruppe, som etter hånden er blitt strengere avgrenset» (2). Denne uttalelsen oppfatter jeg som en avgrensning mot f.eks. tilstander med isolerte, systematiserte vrangforestillinger, slik som paranoia.

Flere internasjonale eksperter holder også fast ved at det faktisk er en viss forskjell på de to begrepene. I en svensk psykiatrilærebok skilles det mellom «paranoiske» og «paranoide» syndromer (3). Det samme gjorde også Gabriel Langfeldt (1895-1983) i læreboken fra 1965, der et kapittel har overskriften Paranoia og paranoiske psykoser (4). Han skilte også mellom paranoide og paranoiske psykopater (5).

Einar Kringlen skriver i sin lærebok om paranoide tilstander: «Det bør for øvrig

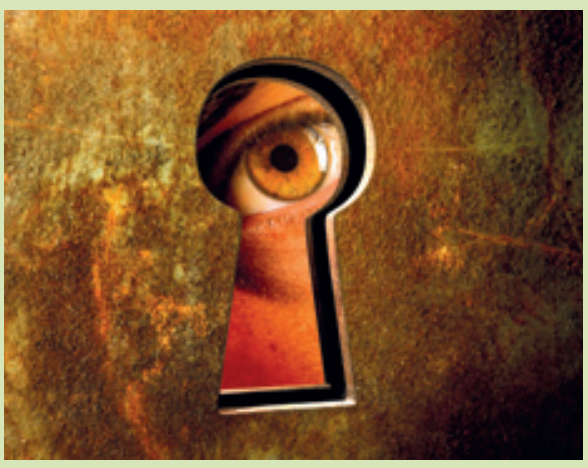

Illustrasjonsfoto @ age fotostock/GV-Press/ NordicPhotos bemerkes at tysk og nordisk terminologi anvender «paranoid» $i$ en videre sammenheng enn den engelske og omfatter ikke bare forfølgelsesidéer, men somatiske, religiøse, hypokondre og grandiose vrangforestillinger» (6).

\section{Forvirrende sammenblanding}

Det har lenge forundret meg at man i den norske oversettelsen av ICD-10 (7) har innført en viss ulogiskhet med hensyn til den innbyrdes rangering av diagnosene «paranoia» og «paranoid». I dagens gjeldende norske versjon heter hovedpunkt F22 paranoide psykoser (vedvarende vrangforestillingslidelser) og punktet F22.0 paranoid psykose (vrangforestillingslidelse). I de diagnostiske retningslinjene anføres at punktet F22.0 inkluderer paranoia. Det er her det ulogiske oppstår, idet paranoia inkluderes «anonymt» $\mathrm{i}$ en større gruppe, mens den altså tidligere sto for seg selv med eget nummer. I den forrige norske utgaven, ICD9 fra 1987 (8), bevarte man den engelske inndelingen (297.0 paranoid state, simple og 297.1 paranoia) og kalte det på norsk tilsvarende 297.00 paranoid psykose og 297.10 paranoia. Den svenske utgaven av ICD-9 (9) var for øvrig helt lik den norske.

I de engelsk-amerikanske versjonene fremkommer ikke lenger dualismen paranoia/paranoid, fordi man der har gått over til å bruke begrepet «persistent delusional disorder» for kategorien F22 i ICD-10 (10). Den svenske utgaven av ICD-10 (11) unngår for øvrig også problemet ved å kalle punkt F22 for «vanföreställningsstörningar», som i den engelske versjonen. For nå å gjøre saken ekstra forvirrende bør nevnes at $\mathrm{i}$ den seneste danske ICD-10utgaven fra 1994 (12) benevnes F22 «enkel paranoia», med latinsk undertekst «psychosis paranoides simplex». Og dermed er sammenblandingen komplett! Altså helt forskjellige ICD-10-versjoner i de tre skandinaviske landene, men det er bare svenskene som har fulgt den internasjonale originalen i oversettelsen.

\section{Forslag til løsning}

Hovedpoenget er at Paranoia helt opp til og med ICD-9 ble utskilt som egen lidelse med eget nummer $\mathrm{i}$ alle de skandinaviske oversettelsene, men at denne overensstemmelsen nå er borte.

Så lenge man i den norske ICD-10 holder fast ved de to begrepene «paranoia» og «paranoid», finner i hvert fall jeg det mest logisk at den lidelsen (paranoia) som en annen lidelse (paranoid) angis å likne på, bør stå først eller øverst, og så bør avledningene komme under eller etter hoveddiagnosen.

Men den beste løsningen er kanskje å gjøre som i den internasjonale engelske versjonen - og som svenskene altså har gjort - sløyfe begrepet «paranoide psykoser» og bare beholde betegnelsen «vrangforestillingslidelser», som hos oss foreløpig står i parentes.

Det ville være interessant å høre hva kolleger mener om dette språklige og systemrelaterte poenget.

\section{Torbjørn Vatnaland}

tovatna@online.no

Svingen 10a

0196 Oslo

\section{Litteratur}

1. Millon T, Grossmann SD, Meagher SE et al, red. Masters of the mind. Exploring the story of mental illness from ancient times to the new millennium. Hoboken, NJ: John Wiley, 2004: 168.

2. Dahl AA, Malt U, Retterstøl NA. Lærebok i psykiatri. 2. utg. Oslo: Gyldendal, 2003: 256.

. Ottosson J-O. Psykiatri. Stockholm: Liber förlag. 2004: 420-36

4. Langfeldt G. Lærebok i klinisk psykiatri. Oslo Aschehoug, 1965: 347

5. Langfeldt G. Lærebok i klinisk psykiatri. Oslo: Aschehoug, 1965: 268

6. Kringlen E. Psykiatri. Oslo: Universitetsforlaget, 1990: 362.

7. ICD-10. Psykiske lidelser og atferdsforstyrrelser. Kliniske beskrivelser og diagnostiske retningslinjer. Ved Statens helsetilsyn. Oslo: Gyldendal Akademisk, 2006.

8. Klassifikasjon av sinnslidelser (ICD-9). Særtrykk av Standard for norsk statistikk 6. Gjeldende fra 1. januar 1987. IK-2206. Oslo: Helsedirekoratet, 1987

9. Socialstyrelsen informerar om Klassifikationsfrågor. (FAP 2). Nr. 2/juni 1989. Stockholm: Byrån för allmänn planering, samhällsplanering och statistik, 1989.

10. The International Statistical Classification of Diseases and Related Health Problems (ICD-10). 2007 Revision. Chapter V F00 - F99. Mental and behavioural disorders. Genève: WHO, 2007.

11. Klassifikation sv sjukdomar och hälsoproblem (KSH97). Stockholm: Socialstyrelsen, 1997.

12. WHO. ICD-10 Kapitel V. Psykiske lidelser og adferdsmæssige forstyrrelser. København: Munksgaard, 1994. 